\title{
PRODUCTION FRAGMENTATION IN TRADE OF MANUFACTURED GOODS IN INDIA: PROSPECTS AND CHALLENGES
}

\author{
Sadhana Srivastava and Rahul Sen*
}

The present paper analyses the phenomenon of production fragmentation in trade of manufactured goods in India, using trade data at the Standard International Trade Classification (SITC) 5-digit product level. It estimates production fragmentation through a decomposition of intra-industry trade in parts and components into horizontal and vertical intra-industry trade over the period 1994-2012. The paper at the product level finds that aircraft parts and automobile parts and the components industry are emerging areas of production fragmentation in manufactured goods trade over this sample period. It further observes that aircraft parts (SITC 79295) is the only parts and component product to undergo product fragmentation at the higher end of the global value chain and that the auto parts and components industry is found to be experiencing this primarily at the lower end of the value chain. The findings are consistent with the existing literature supporting the view that to harness the existing potential of fragmentation that exists in these industries, Indian policymakers need to create a business environment conducive for moving up the quality ladder in the global value chain.

JEL classification: F14, R11, F12.

Keywords: Production fragmentation, India, horizontal and vertical intra-industry trade, VIIT, parts and components, value chain.

Sadhana Srivastava (e-mail: sadhana.srivastava@aut.ac.nz), and Rahul Sen, corresponding author, Senior Lecturer (e-mail; rahul.sen@aut.ac.nz), are from Department of Economics, Private Bag 92006, AUT Business School, Auckland, New Zealand. We would like to thank Soudachanh Darounphanh for her invaluable research and three anonymous referees for their comments on an earlier version of this paper. The usual disclaimer applies. 


\section{INTRODUCTION}

International production fragmentation broadly refers to the splitting up of a good into its constituent parts, components and accessories that are produced, traded and distributed across spatially dispersed locations on the basis of their comparative advantages. ${ }^{1}$ This phenomenon enables multinational firms to specialize by tapping a country's comparative advantage originating in a particular stage of the production sequence along its global value chain, creating international production networks in manufactured goods. Trade involving production fragmentation has contributed to an increasing share of intra-industry trade (IIT) in manufactured goods, involving twoway trade in intermediate goods belonging to a single industry but at different stages of production. This is also referred to as "vertically specialized trade" and "network trade" in the evolving literature on global production fragmentation, ${ }^{2}$ that includes trade in parts and components, as well as in final assembly goods. Athukorala (2011) estimates that this trade accounted for nearly a half of total world manufacturing trade in 2007.

While the empirical measurement of production fragmentation is a debatable issue, studies, such as Fukao, Ishido and Ito (2003), Ando (2006), Turkcan and Ates (2010) and, more recently Tewari, Veeramani and Singh (2015) have used vertical intra-industry trade (VIIT) in intermediate goods resulting from production-sharing activities as an appropriate indicator of production fragmentation for a particular industry. VIIT refers to IIT based on product differentiation due to quality differences between exports and imports, and has been measured by the ratio of the unit value of exports to the unit value of imports for each product in the past empirical literature. ${ }^{3}$

Vertically specialized trade has been quite pervasive in East Asia since the 1980s. Studies, such as Fukao, Ishido and Ito (2003), Kuroiwa and Heng (2008), Fujita (2007) and Athukorala $(2011,2013)$ have observed that multinationals involved in labour-intensive manufacturing industries, such as automobiles and electronics, in East Asian countries have been heavily involved in such production fragmentation-based trade. These studies also argue that the adoption of an export-led growth strategy by most East Asian countries in the 1980s involving foreign direct investment (FDI) contributed to a rapid expansion of their share of intra-industry trade in machinery parts and components.

See Rajan (2003); Hummels, Ishii and Yi (2001); Yi (2003); Krugman (1995); Ng and Yeats (2001, 2003); Grossman and Helpman (2005).

See Ando (2006); Fukao, Ishido and Ito (2003); Athukorala (2011); Tewari, Veeramani and Singh (2015); Jiang and Milberg (2012); Turkcan and Ates (2010); and Pittiglio (2014) among others.

$3 \quad$ See Greenaway, Hine and Milner (1995); Fontagné and Freudenberg (1997); Ando (2006). 
The experience of India has been quite distinct to the above phenomenon. In spite of the country's geographic proximity to East Asia, its economy has followed an entirely different growth strategy ${ }^{4}$ in which it was largely left out of the global division of labour in the 1990s, particularly with regard to parts and components production. ${ }^{5}$ Tewari, Veeramani and Singh (2015) argue that one of the primary reasons for the lack of involvement in global production fragmentation in trade of manufactured goods was because policymakers in India had failed to make adequate efforts to improve the competitiveness of the manufacturing sector and to address major supply side bottlenecks.

Notwithstanding the above policy deficit, the composition of the trade basket of India has changed considerably in recent decades, with traditional resources-based products, such as textiles, clothing, gems and jewelry, which were predominate in the 1980s and 1990s, replaced by skill-intensive-based goods, such as metal and non-metal goods and chemicals, in second-half of the 1990s; the trend since then is moving towards technologically intensive-based goods (Felipe, Kumar and Abdon, 2013). The economy of India is rapidly growing. It is currently the third largest economy in the world in terms of purchasing power parity (PPP) ${ }^{6}$ and its rankings in world trade in both merchandise trade ${ }^{7}$ and in commercial services ${ }^{8}$ have risen dramatically. With the opening up of its economy to foreign investors starting in 1990 s and the liberalization of regulatory procedures, including the lifting of quantitative restrictions on imports and tariff reductions, India has deepened its trade and investment linkages with rest of the world over the past decade. It is involved in a number of economic integration initiatives with East Asia through a web of bilateral and multilateral trade and economic cooperation agreements as a part of its "Look East Policy", with the more recent one being the Regional Comprehensive Economic Partnership (RCEP)

India followed a socialist planning model from independence and focused heavily on self-reliance and import-substitution as a growth strategy up until 1991. It embarked on an outward-oriented growth strategy about a decade later than most East Asian countries.

$5 \quad$ See Rajan and Sen (2002); Tewari, Veeramani and Singh (2015).

$6 \quad$ In 2012, the GDP of India at PPP was about \$4.8 trillion (World Bank, 2012).

$7 \quad$ From being one of the relatively insignificant players in global trade in the 1980s (ranked below the 40th position globally), the country's ranking climbed to 19th among the world's merchandise exporters (constituting a share of 1.6 per cent of world's merchandise exports) in 2012 and 10th among the world's merchandise importers, (constituting a share of 2.6 per cent of world's merchandise imports) in the same year.

8 In the area of trade in commercial services, India fared better globally than in merchandise trade, with a ranking of 7 th among world exporters and importers of commercial services (constituting a share of 3.0 per cent of world's service exports and imports), in 2012, compared to 34th and 28th, respectively in 1995 (WTO, 2013). Among developing countries, India was ranked as the second largest exporter of commercial services in 2012, behind China (WTO, 2013). 
agreement involving India and 15 other member countries. ${ }^{9}$ Following the above developments, it is of interest to examine whether production fragmentation has been emerging in the country's trading of manufactured goods since the post-reform period, and if so, in which industries and products.

The empirical evidence in the context of India to date has been quite sparse. The empirical analyses have mainly evolved through the studies on intra-industry trade of manufactured goods in the country or using descriptive statistics that reflect the importance of trade in intermediate goods. For example, studies, such as Veeramani (2002, 2009), Srivastava and Sen (2011, 2012), and Amighini (2012) have investigated production fragmentation using indices of intra-industry trade, but for a shorter time-span up until 2008. However, none of them have separated IIT in parts and components products into horizontal and vertical IIT for capturing the extent of global production fragmentation evolving in intermediate goods trade. Two recent studies, namely Athukorala (2013) and Tewari, Veeramani and Singh (2015), investigate the prospects of global production sharing in India compared with East Asia and ASEAN, respectively. Tewari, Veeramani and Singh (2015) in the context of analyzing production fragmentation in bilateral trade between India and ASEAN during the period 2000-2011, noted that in spite of low volumes, there is evidence of increasing vertically specialized trade between them.

The present paper departs from the earlier works by incorporating a longer sample covering the post-reform time period of 1994-2012 and using product-level disaggregation at the Standard International Trade Classification (SITC) 5-digit level. It focuses on specific product categories in which VIIT in parts and components trade is highly concentrated, involving an inter-temporal comparison over the sample period under study.

The remainder of the paper is organized as follows: section II reviews the theoretical and empirical literature on international production fragmentation, focusing on the specific studies in the Indian context; section III analyses emerging trends in the country's trade of total merchandise and parts and components trade and identifies the top ten exports and imports under the parts and components product categories; section IV details the empirical measurement issues and undertakes an estimation of actual and marginal intra-industry trade in parts and components, decomposing it further into horizontal and vertical IIT that captures the magnitude of product fragmentation in the trade flows; and section $\mathrm{V}$ provides policy implications from the above analysis, and concludes the paper.

This includes the 10 ASEAN member States, as well as China, Japan, the Republic of Korea, Australia and New Zealand. 


\section{LITERATURE REVIEW}

\section{Theoretical literature}

According to Gereffi (2001), the phenomenon of international production fragmentation can take place through two channels. The first is by subcontracting, which involves arm's length transactions, wherein a firm can contract an overseas supplier to manufacture parts and components, while retaining key service functions, such as research and development and designing. ${ }^{10}$ The second involves creating international production networks (via FDI), resulting in vertically specialized trade. FDI-led international production networks are largely driven by multinationals involved in high technology, capital intensive production of customized and specialized parts and components wherein quality considerations and asset specificity ${ }^{11}$ are paramount.

Gereffi (2001), therefore, classifies production fragmentation into two categories based on its drivers. The first is buyer-driven production fragmentation, which is more common in industries that exhibit low barriers to entry in production and possibilities of arms-length transactions, such as in garments, footwear, furniture and toys. The related global commodity chains of the above industries are usually controlled by large firms at the design and retail ends of the value added chain, with little or no scope for vertically specialized trade.

The second category is producer-driven fragmentation, which is significant in industries that are characterized by industrial capital and vary in their core competencies and entry barriers (Gereffi, 2001, table 1, p. 1622). In this case, the producer-driven types of commodity chains are controlled by large manufactures at the point of production, research and development, and design and are usually led by multinational corporations playing the central roles of coordinating production networks that include backward and forward linkages. Such linkages create opportunities for vertically specialized trade and are mainly driven by cost and quality considerations based on international division of labour and economies of scale (Helpman, 1984).

It has been observed that industries, such as semiconductors, automobiles and heavy machinery, are typically characterized by producer-driven fragmentation, enabling different countries in the production network to gain from contributing to the global value chain of an industry.

\footnotetext{
10 An example of this would be Sweden-based IKEA Home Furnishings entering into a contract with Polish and Vietnamese firms to manufacture furniture items for it, while they concentrate on the design of those items (Athukorala, 2013).

11 Asset specificity involves investment in dedicated physical or human assets unique to the specific production process. An example would be molds in the glass container production process that are custom made to create specific shapes of the containers.
} 
New trade theories (Dixit and Stiglitz, 1977; Helpman and Krugman, 1985) dealt with two-way trade in horizontally differentiated final consumer goods due to economies of scale and product differentiation. More recently, Lüthje (2001) argued that the same can also be applied to intermediate goods as horizontal IIT in intermediate goods occurs since producers buy only a particular variety of intermediate goods that best meets the specific needs of production. This allows the final goods producer to use a specific variety of intermediate goods, such as an "ideal intermediate good", in the production of the specific variety of final goods.

Jones and Kierzkowski (1990) were the first researchers to establish theoretically that vertical specialization-based trade occurs as a result of production fragmentation. They observed that the basis for vertical specialization in intermediate goods arises as a result of the relative differences between factor endowments and factor intensities in the component production, thereby driving vertical two-way trade in intermediate goods. ${ }^{12}$ Yi (2003) has further explained how technological and organizational innovations improve the possibilities of slicing up the production process and the global reduction in trade barriers. These, in turn, lead to lower cost of production from the input stage to distribution, and creates incentives for locating different stages of production across countries. Kimura and Ando (2005) further recognize the importance of spatial interdependence (geographical interdependence of production blocks), which reduces service link costs. Ando and Kimura (2009) apply this to East Asia and argue that such sophisticated networks, in turn, provide opportunities for indigenous firms to penetrate into production networks developed by multinational enterprises. This new form of trade and FDI, which has been much observed in East Asia, contributes to the unprecedented phenomenon of production fragmentation.

\section{Empirical literature}

In order to yield meaningful estimates of production fragmentation, it is important to qualify as to why the data on parts and components (that proxy for production fragmentation) need to be separated out from the reported overall trade statistics. According to Athukorala and Yamashita (2005), there are primarily two reasons for such segregation: (i) production fragmentation may lead to double-counting of trade data when the same parts and component used as an input for the final good crosses multiple international borders during production stages; and (ii) the calculated trade share can, therefore, provide incorrect inferences as to the relative importance of a "region" vis-à-vis the rest of the world. This has been observed to be particularly significant in the case of East Asia where trade in parts and components and trade in final goods did not follow the same patterns.

Also see Jones and Kierzkowski (2001). 
Furthermore, there are important data caveats involved in analysing production fragmentation in international trade. While the data available from the United Nations trade database based on revision 3 of the Standard International Trade Classification (SITC, Rev. 3) are widely used, there are issues with its coverage at the disaggregated product level. For instance, SITC, Rev. 3 data do not cover the entire range of industries involving production fragmentation, apart from products in machinery and transport equipment (SITC 7). In addition, international production fragmentation is not just limited to SITC 7 and SITC 8 (miscellaneous products), but is also prevalent in pharmaceutical and chemical products (SITC 5) and manufactured products (SITC 6), as well as in the assembly of software trade, which is often lumped with the category of "special transactions" under SITC 9. Therefore, one can infer that estimates of trade in parts and components that emerge from SITC, Rev. 3 data will very likely be downward biased. It may be argued that this downward bias is likely to be serious for India because its manufacturing trade is more diversified with a greater share of SITC 5 and SITC 6 that includes gems and jewelry and chemicals. Furthermore, recent studies on India such as Athukorala (2013), drew attention to the fact that the ongoing process of global production sharing and network trade based on parts and components is heavily concentrated in SITC 7 and SITC 8, and that there is virtually no product that is likely to be produced from start to finish, specifically in those two categories. Therefore, analysing the manufacturing of parts and components in these two specific industry groups for estimating production fragmentation is appropriate.

Since production fragmentation involves two-way trade, such as exports and imports, within the same industry and product category, the empirical literature on estimating production fragmentation has largely evolved from that of estimating intra-industry trade. In addition to addressing the methodological issues related to measurement of intra-industry trade, the empirical literature has further argued the need to review IIT based on the nature of product differentiation involved. Studies, such as Greenaway, Hine and Milner (1995) and Fontagné and Freudenberg (1997), have grouped IIT into two types: the first is horizontal IIT, wherein firms in each country would manufacture a subset of the varieties within an industry and export them for final demand, importing the other varieties. This kind of IIT is not based on differences in quality, but instead it is determined by attributes of the final good. The second type is VIIT based on differences in quality and factor endowments, wherein the gap between the unit value of imports and the unit value of exports for each good reveals the qualitative differences between them.

Several empirical studies, such as Fukao, Ishido and Ito (2003), Ando (2006), Turkcan and Ates (2010), Amighini (2012), and more recently Tewari, Veeramani and Singh (2015) have used (VIIT) in intermediate goods resulting from production sharing activities as an indicator of production fragmentation for a particular industry. 
They argue that unit-price differentials outside a certain range ${ }^{13}$ may reflect not only differences in quality, but also back-and-forth transactions with value-added embodied in vertically fragmented production processes. Therefore, the trade pattern categorized as vertical IIT could partially reflect international fragmentation in the same commodity category, if the ratio of export unit value to import unit value for each parts and components product category is outside the range of 0.75 to 1.25 . Furthermore, if these ratios are found to be above 1.25, it suggests that (a) parts and components export prices are higher than parts and components import prices, (b) the quality or processing stage of exports is higher than that of imports; and (c) a country is experiencing a high-quality VIIT that involves product fragmentation in activities concentrated in the higher end of the value chain.

\section{Studies on India}

In the Indian context, Veeramani $(2002,2009)$ extensively conducted research on intra-industry trade for the manufacturing sector, identifying the trends and their key determinants. Veeramani (2002) reviewed trends in the overall intra-industry trade over the time periods 1998, 1995 and 2000, and further analysed the determinants of bilateral IIT of India with its 51 trading partners in 1999. This study estimated IIT using 4-digit Indian Trade Classification (ITC) data at the industry level. It employed the G-L index and an additional measure of marginal IIT, as suggested by Brülhart (1994), to understand changes in levels of IIT. It observed that IIT has grown significantly over these time periods, and that it responded positively to economic reforms that have unleashed a series of trade and investment liberalization measures since the 1990s.

Furthermore, in order to estimate the effect of FDI on IIT, Veeramani (2009) evaluated the effect of trade barriers and multinationals on IIT in India across 75 industries using the same classification over the period 1988-1999 using panel regressions. The analysis suggested that reduced trade barriers influence IIT in a positive way, and that IIT is negatively influenced as a result of a high tariff regime. As a result, this generated more market-seeking FDI, wherein the foreign investor's motive was to serve in the domestic market rather than utilize it as a global export platform. ${ }^{14}$ However, Kumar (2003) is among the few studies on FDI that note that

\footnotetext{
13 These studies employ a 25 per cent threshold of relative unit values of exports to imports to distinguish between horizontally and vertically differentiated products.

14 This view of market-seeking motives driving Indian FDI in manufacturing has been empirically established by several studies, including among others, Aggarwal (2001); Kumar and Siddharthan (1994); Kumar (1990); and Pant (1993, 1995). A suitable example would be Honda, a Japanese automobile manufacturer, opening a manufacturing plant in India with a view to specifically target customers in the Indian automobile market.
} 
reforms have prompted foreign multinationals to begin to explore the potential of India as an export-platform production in a modest manner.

More recent studies on production fragmentation in India are Athukorala (2013) and Tewari, Veeramani and Singh (2015). Athukorala (2013) estimated the country's share in global network trade based on production fragmentation compared to East Asia. It was observed that during the periods 1990-1991 and 2010-2011, network goods accounted for only about 22 per cent of the total increment in manufacturing exports from India compared with 70 per cent for East Asia. He argued that this does not lend strong support to India entering into global and regional production networks in electronics and electrical goods, which have been the prime mover of export dynamism in successful export-oriented economies in East Asia. Furthermore, the study noted that there had been a noticeable increase in network trade involving the transport equipment sector, but not in high-tech industries, suggesting that international production fragmentation in India was mainly in the lower end of the value chain. This study did not estimate production fragmentation using intra-industry trade analysis. Instead, it analysed the determinants of such fragmentation for India when compared with East Asia in an applied augmented gravity framework.

Tewari, Veeramani and Singh (2015) confirm some of the above trends identified by Athukorala (2013), and apply detailed intra-industry analysis at the harmonized system (HS)-6 digit level to estimate the production fragmentation in trade of manufactured goods involving bilateral trade between India and ASEAN. This study supplements primary data from firms and argues that while India imported products of a higher value or stage of processing from ASEAN than it exports to the region, there is an urgent need for Indian firms to upgrade on the quality ladder of the global value chain. This study used disaggregated data at the HS-6 digit level, which is not the highest level of disaggregation in the HS classification. Consequently, 6-digit codes may overlap with three or four 8-digit codes under them, and India may be exporting mainly one 8-digit category and importing another 8-digit category. The study notes that the automotive industry appeared to be one of the few sectors in India that is linked to global production networks, and therefore is likely to involve production fragmentation.

Amighini (2012) compares international fragmentation of China and India specifically in this industry during 1995 and 2008 using intra-industry trade analysis as followed in the empirical literature. It concludes that VIIT has dominated exports of India in this industry, and the evidence points towards fragmentation in this industry at the lower quality ladder.

Compared to the above studies on India, this paper attempts to estimate production fragmentation in manufacturing at the highest level of product disaggregation 
using SITC classification (SITC 5-digit) ${ }^{15}$ and focusing on an extended time period that captures the trends in production fragmentation over nearly the two decades since economic reforms were initiated in India. These reforms were intended to reduce or eliminate trade and investment barriers and make it easier to export and as a result enable the country to participate in global value chains and international production fragmentation.

\section{PRODUCTION FRAGMENTATION IN TRADE OF MANUFACTURED GOODS: TRENDS AND PATTERNS}

\section{Total manufacturing trade}

The manufacturing sector constituted about two thirds of total merchandise exports in India and more than half of the country's merchandise imports from 2005 to 2009 (tables 1 and 2). Exports of manufactured goods were dominated by the increasing share of SITC 6 and 8 products, such as gems and jewelry, and clothing and footwear. In addition, the share of machinery and transport equipment (SITC 7), consisting of parts and components of electronic products and electrical machinery and parts of transport vehicles and equipment, in total manufacturing exports, rose from 9.5 per cent to 13.6 per cent between 1994 and 2008, and then increased further to 21.4 per cent in 2012 . This category constituted 20 per cent of total manufacturing imports in 2008 and 31 per cent of it in 2012.

\section{Parts and components trade}

The list of parts and components identified at the 5-digit level for SITC 7 and SITC 8 products from the UN Comtrade database (United Nations, 2014) contains 231 SITC five-digit products - 172 products belonging to SITC 7 and 59 belonging to SITC $8 .{ }^{16}$ Annex 1 provides the detailed commodity classification for the top 10 products of the parts and components sector in manufacturing exports and imports of India. ${ }^{17}$ As trade in parts and components is unlikely to substantially change on an annual basis, an inter-temporal comparison is appropriate. The analysis compares parts and components trade patterns for the years 1994, 2004, 2008 and 2012.

\footnotetext{
15 It is important to note that when trade data at the 5-digit SITC level are extracted, there may be a risk of eliminating several 4-digit SITC items (for which there are no further disaggregations at the 5-digit level) from the analysis. However, this risk has not been observed for the manufacturing parts and components categories analysed in this study.

16 This list is adapted from Athukorala (2005, appendix A-5).

The detailed data on all products are available from the authors on request. Most of the remaining parts and components products constituted a share of 1 per cent or less and are hence not reported in these tables.
} 


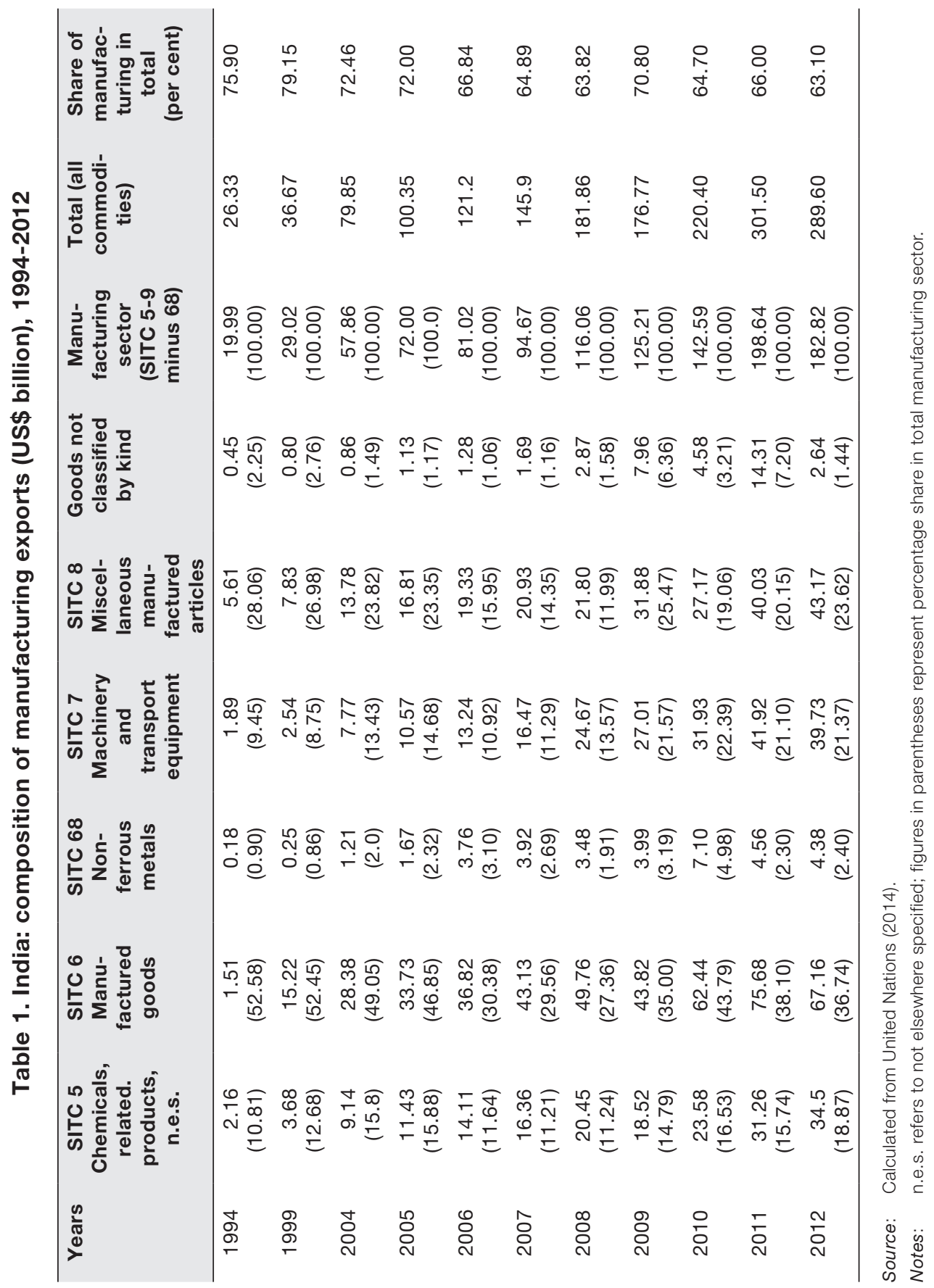




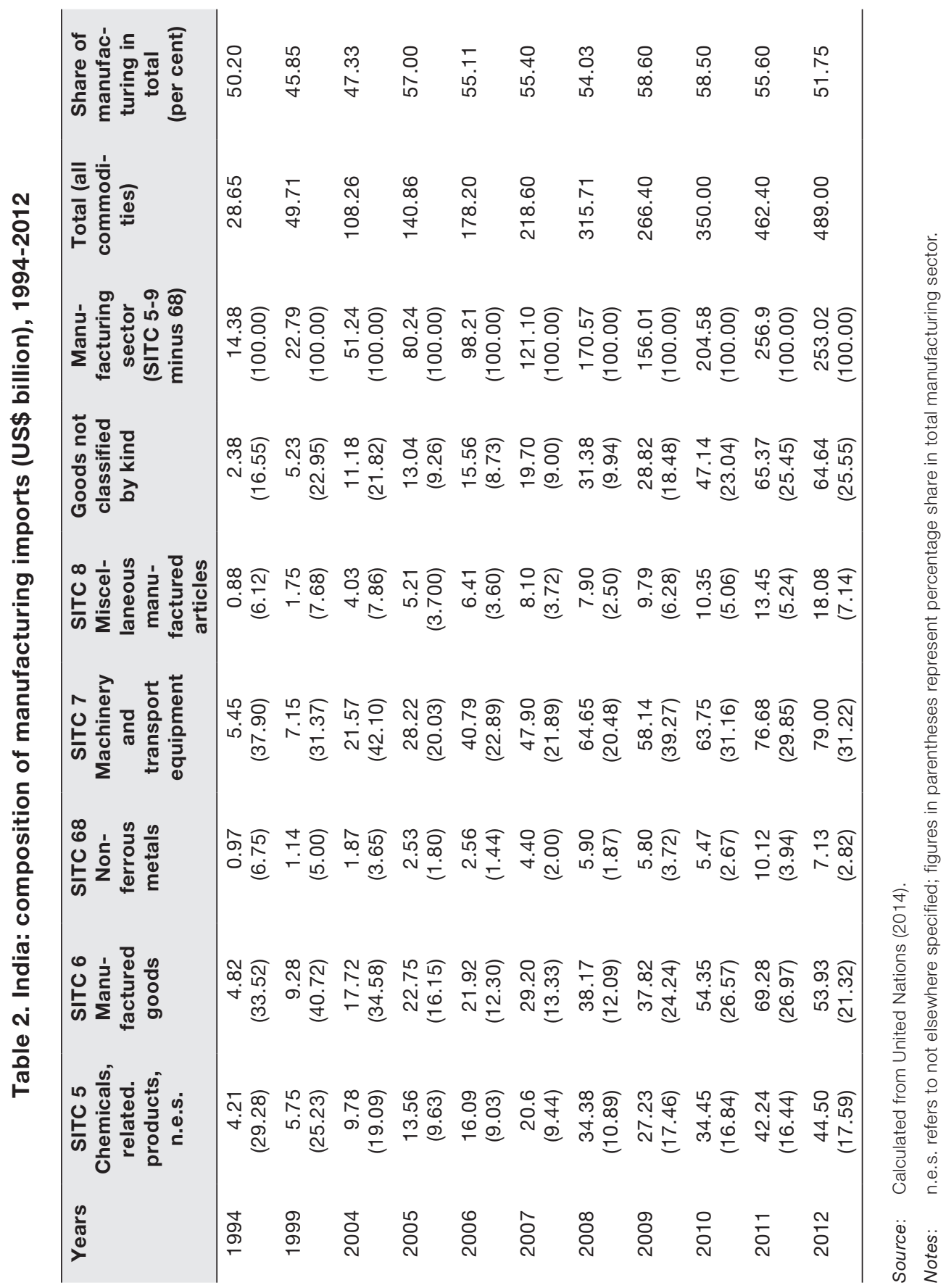


Table 3 identifies the trends in the top 10 parts and components products that were exported during the period 1994-2012. These constituted about 70 per cent of parts and components exports in categories SITC 7 and 8 from India. It is observed that parts for automobiles and other vehicles (categories SITC 784 and SITC 785), as well as those for electrical, electronic and telecommunication equipment (categories SITC 75 to 77 ) constituted the bulk of the parts and components exports of manufactured goods in India during the decade. Total parts and components exports expanded in volume from $\$ 636$ million to $\$ 13$ billion over the period 1994-2012, growing at a compound rate of 18.3 per cent annually and increasing its share in total exports of manufactured goods from 3.2 per cent in 1994 to about 7.0 per cent by 2012. Given that world exports of parts and components in 2008 was worth $\$ 1,118$ billion, the contribution of India to global parts and components exports is minimal.

The above shares are also significantly lower than the case for exports of other developing economies in Asia (particularly East Asia). ${ }^{18}$ Notably, the growth of exports of parts and components in India has been significantly higher than that of total exports of merchandise goods and manufactured goods over the past decade. This is an indication of the increasing importance of parts and components exports over the past decade (figure 1). In spite of the slowdown in world growth with the onset of the global economic crisis in 2008, India registered a phenomenal growth rate of 44.4 per cent in its parts and components exports between 2007 and 2008, while its total manufacturing exports registered negative growth of 1.6 per cent. The compound average growth rate for parts and components exports during the period 2008-2012 was 11.3 per cent compared to 12 per cent for total manufacturing exports.

A similar trend has occurred with regard to parts and component imports in India, particularly during the period 1999-2012 (figure 2).

Table 4 identifies the trends in top 10 products of manufactured parts and components imports during the period 1994-2012. These constituted about 62 per cent of total parts and components imports in categories SITC 7 and 8 by India. Notably, one product, namely other parts and accessories of the motor vehicles of groups 722, 781, 782 (SITC 78439), has been among the most important component of parts and components imports by India. In addition, parts and accessories for data processing machines (SITC 75997) also figure among the important components of parts and components imports. These two products comprised about a quarter of total parts and components imports in 2004. Parts of electrical, electronic and telecommunication equipment (categories SITC $71,72,75$ to 77 ) have constituted the

18 See Athukorala (2011). 


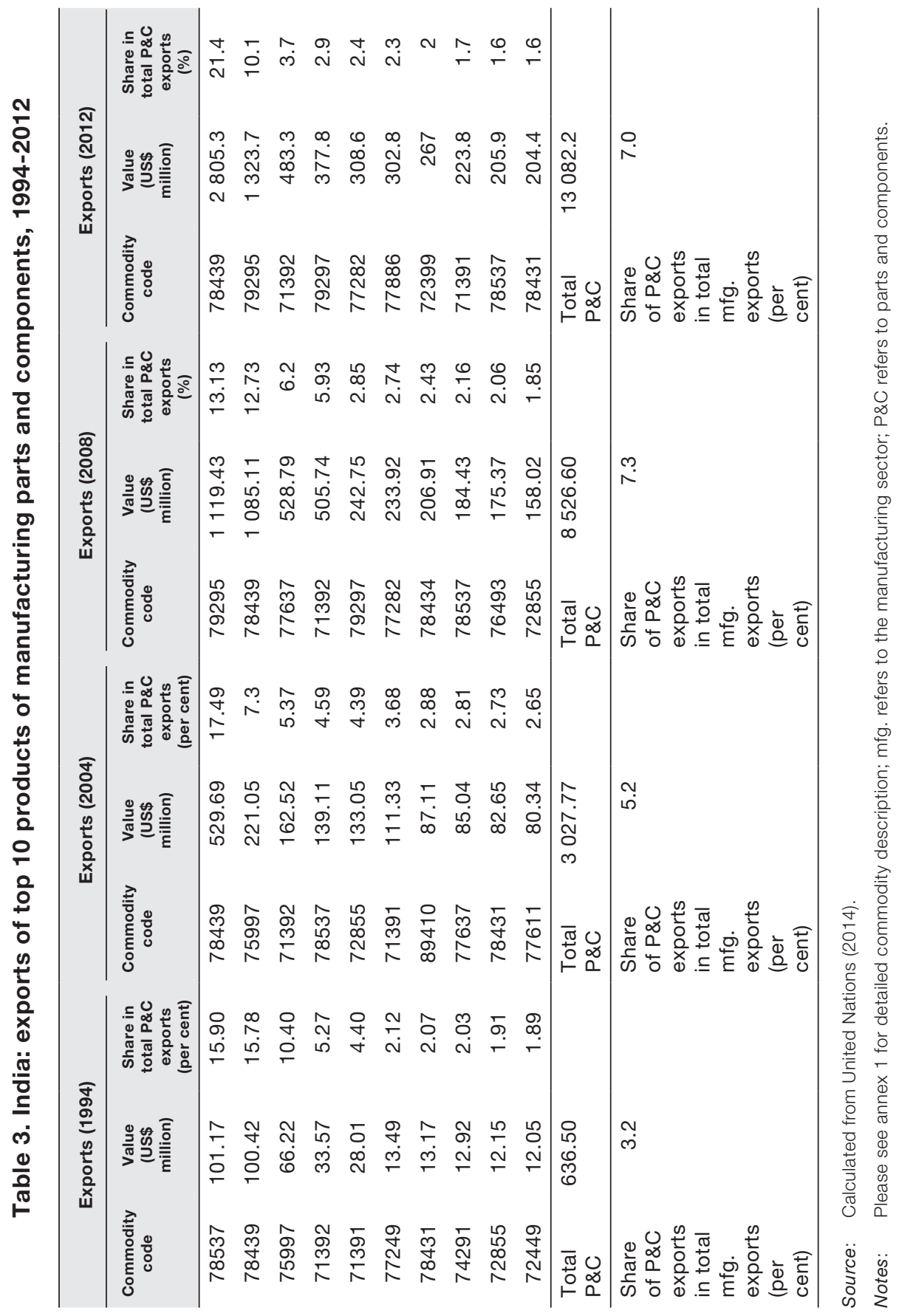


Figure 1. Growth in merchandise exports from India: 1994-2012

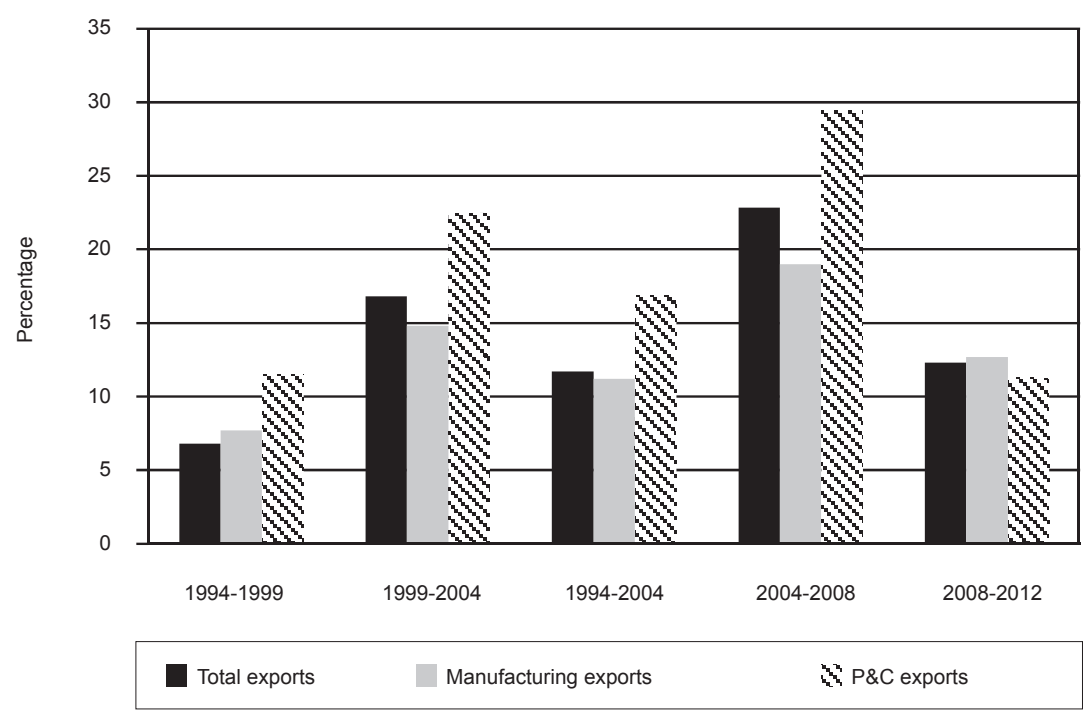

Source: Author's calculations based on United Nations (2014).

Note: $\quad$ P\&C refers to parts and components.

Figure 2. Growth in merchandise imports in India: 1994-2012

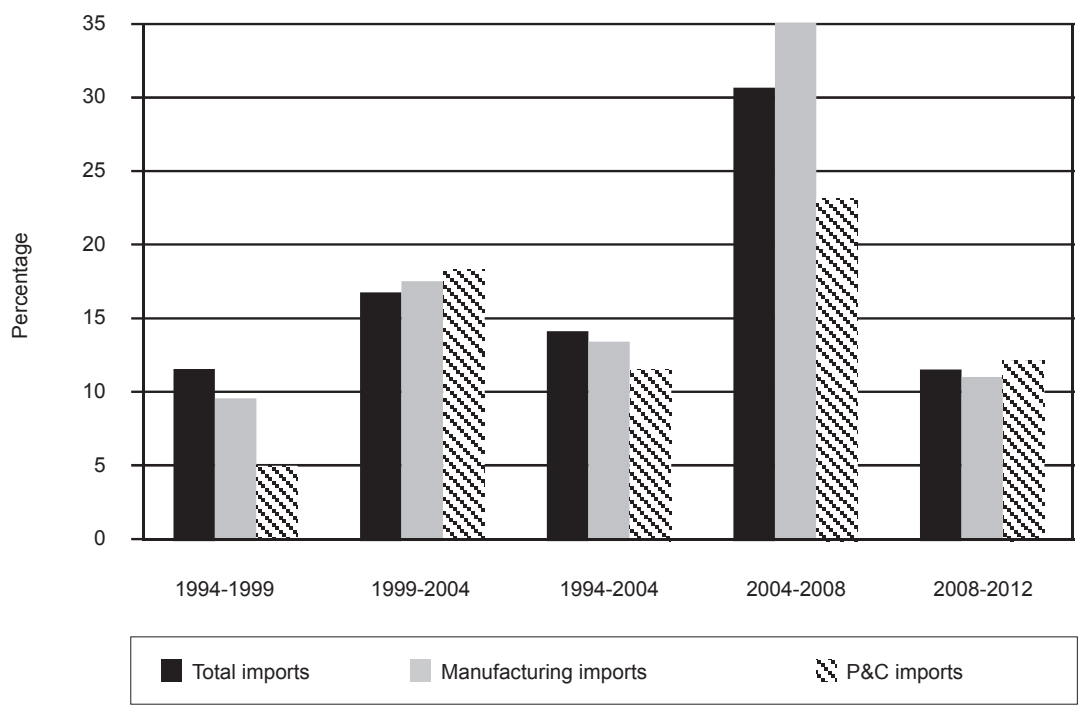

Source: Author's calculations based on United Nations (2014). 
bulk of parts and components imports in the manufacturing sector over the decade. Total parts and components imports more than tripled in volume from $\$ 2.3$ billion to $\$ 7.0$ billion over the period 1994-2004, at a compound annual growth rate of 11.6 per cent, and then increased to $\$ 25.6$ billion in 2012 , at a compound annual growth rate of 12.2 per cent over the period 2008-2012. Given that global imports of these parts and components in 2008 was worth $\$ 1.044$ billion, it can be inferred that the contribution of India to parts and components imports globally (about 0.7 per cent) has been low as well.

A comparison of tables 3 and 4 indicated that over the period 1994-2012, the share of parts and components exports in total manufacturing exports more than doubled while that of parts and components imports declined from 16.3 per cent to 5.3 per cent. This is the result of the gradually easing of reliance on imported intermediate inputs in manufacturing during post-economic reforms by Indian firms. Furthermore, it is notable that several products in which the parts and components category that are both imported by and exported from India, were also above average in size and growth compared to the other parts and components products traded. In 1994, these included five products out of the top 10 parts and components exports and imports, namely SITC 78439, 75997, 71392, 78431, and 72449. In 2008 and 2012, two of those products, namely SITC 78439 and 71392, remained in the top 10 ranking which also included new parts and component products, namely SITC 79295, 77282 and 72399 (tables 3 and 4). By 2012, the share of the top ranked parts and components export and import product SITC 78439 increased its share in parts and components exports to 21.4 per cent compared with 12.7 per cent in $2008 .^{\circ}$

The above trend in trading of manufactured parts and components indicates that intra-industry trade is taking place in these product components and accessories, meaning that the import and export of goods pertaining to the same classification are occurring simultaneously. As this category comprises machinery, electronics, and auto parts and vehicle components, further analysis of intra-industry trade is required to ascertain whether product fragmentation is likely being experienced in these sectors in the Indian economy over the chosen sample period. 


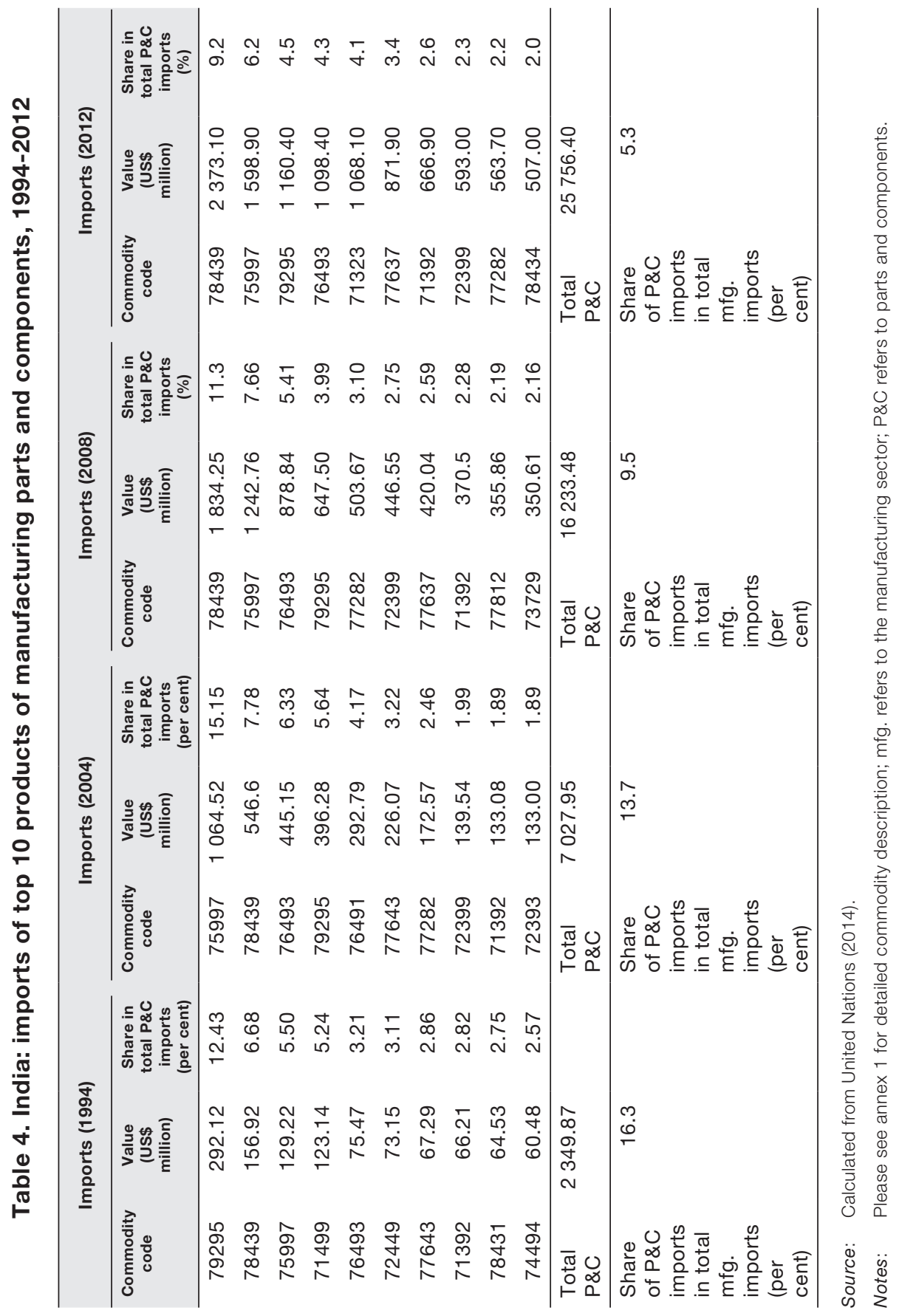




\section{Estimating production fragmentation in trade of parts and components in India methodology}

The methodology involved in empirically estimating production fragmentation in trading parts and components in India involves several steps. ${ }^{19}$

The first step entails applying the methodology of Abd-el-Rahman (1991) and Ando (2006) in order to disaggregate trade of commodity $j$ in terms of one-way trade or intra-industry trade. This decomposes total trade of parts and components into one-way trade (inter-industry trade explained by the traditional comparative advantage theory) and two-way trade that involves intra-industry trade associated with fragmented production chains. A certain range of overlapped values of exports and imports are used. Specifically, trade of commodity $j$ is regarded as one-way trade when the following equation (1) holds and intra-industry trade otherwise:

$$
\operatorname{Min}\left(X_{k j}, M_{k j}\right) / \operatorname{Max}\left(X_{k j}, M_{k j}\right) \leq 0.1
$$

Where $X_{k j}$ represents country $k$ 's exports of commodity $j$ to the world, and $M_{k j}$ the country $k$ 's imports of commodity $j$ from the world.

The second step is the application of the Grubel and Lloyd (1975) (G-L) index to the list of two-way products to estimate the degree of IIT in that product. The Grubel-Lloyd (G-L) index measures the ratio of net exports in a product category to its total trade in an index that takes values from 0 to 100 . It also calculates the part of balanced trade (overlap between exports and imports) in all trade in a given product $j$. The index is calculated by the following formula $G-L$ index for a given product $j$ is denoted as

$$
G-L_{j}=1-\frac{\left|X_{j}-M_{j}\right|}{X_{j}+M_{j}}
$$

Where $X_{j}$ refers to exports and $M_{j}$ refers to imports in the same product.

This index takes a value of zero if either $X_{j}$ or $M_{j}$ equals zero implying no IIT and if $X_{j}=M_{i}$, it implies a value of 100 and signifies complete IIT in that product. However, this index is observed to measure an incorrect level of IIT, especially if trade imbalances are higher. Studies, such as Rajan (1996), have argued that G-L is a degree of measure of IIT rather than the absolute amount. There needs to be a distinction between the level of IIT and the actual amount of IIT that takes place, and the degree or extent of IIT. The level of IIT is estimated separately for these products as

19 See Srivastava and Sen (2011). 


$$
L_{j}=2 * \min \left(X_{j}, M_{j}\right)
$$

For the $j^{\text {th }}$ product where $X_{j}$ refers to exports and $M_{j}$ refers to imports in the same product.

The third step is to analyse the estimates of marginal IIT as suggested by Brülhart (1994) to ascertain whether the change in trade volumes over the time periods analysed are more due to intra-industry or inter-industry trade. This measure, known as Marginal IIT (MIIT), is a transposition of the G-L index using first differences of trade flows, and is measured for the $\mathrm{j}^{\text {th }}$ product as:

$$
M I I T_{j t}=1-\frac{\left|\Delta X_{j t}-\Delta M_{j t}\right|}{\left|\Delta X_{j t}\right|+\left|\Delta M_{j t}\right|}
$$

Where $\Delta$ stands for the first difference operator and measures, the change in values of exports or imports of the $j^{\text {th }}$ product in time period $t$ compared to a reference year. This index also takes values from 0 to 1 , and in percentage terms goes from 0 to 100 as the G-L index. A MIIT value close to 100 indicates marginal trade over the time period to be of the intra-industry variety and inter-industry if the MIIT index is 0 or closer to it.

The final two steps are applied to the parts and components product groups identified to experience highest levels of two-way IIT trade over this period in order to decompose IIT in these categories into horizontal and vertical IIT, and further into low- and high-quality VIIT to estimate production fragmentation. Following Greenaway, Hine and Milner (1995), Fukao, Ishido and Ito (2003), Ando (2006), Amighini (2012), and Tewari, Veeramani and Singh (2015), intra-industry trade of commodity $j$ is regarded as horizontal IIT when the following equation (5) holds and as vertical IIT otherwise:

$$
\frac{1}{1.25} \leq \frac{P_{k j}^{X}}{P_{k j}^{M}} \leq 1.25
$$

Where $\mathrm{P}_{\mathrm{kj}} \mathrm{x}$ expresses the unit value of commodity $j$ exported to the world by country $k$, and $\mathrm{P}_{\mathrm{kj}}{ }^{\mathrm{M}}$ the unit value of commodity $j$ imported from the world by country $k$.

Following the general practice in the empirical literature, ${ }^{20}$ if the ratio of the unit value of exports to import is greater than 1.25, then the quality or processing stage of exports is higher than that of imports and thus categorized as high-quality (HVIIT), while ratios below 0.75 may indicate higher quality or processing of imports compared with exports categorized as low-quality (LVIIT).

20 See Durkin and Krygier (2000); Fukao, Ishido and Ito (2003); Tewari, Veeramani and Singh (2015). 


\section{Results}

Figure 3 decomposes the pattern of trade of parts and components in India over the period 1994-2012 into one-way and two-way trade. It is observed that the share of two-way trade, which represents IIT, increased from 53.7 per cent to 81.0 per cent over the specified period.

\section{Figure 3. Patterns of trade in parts and componets in India}

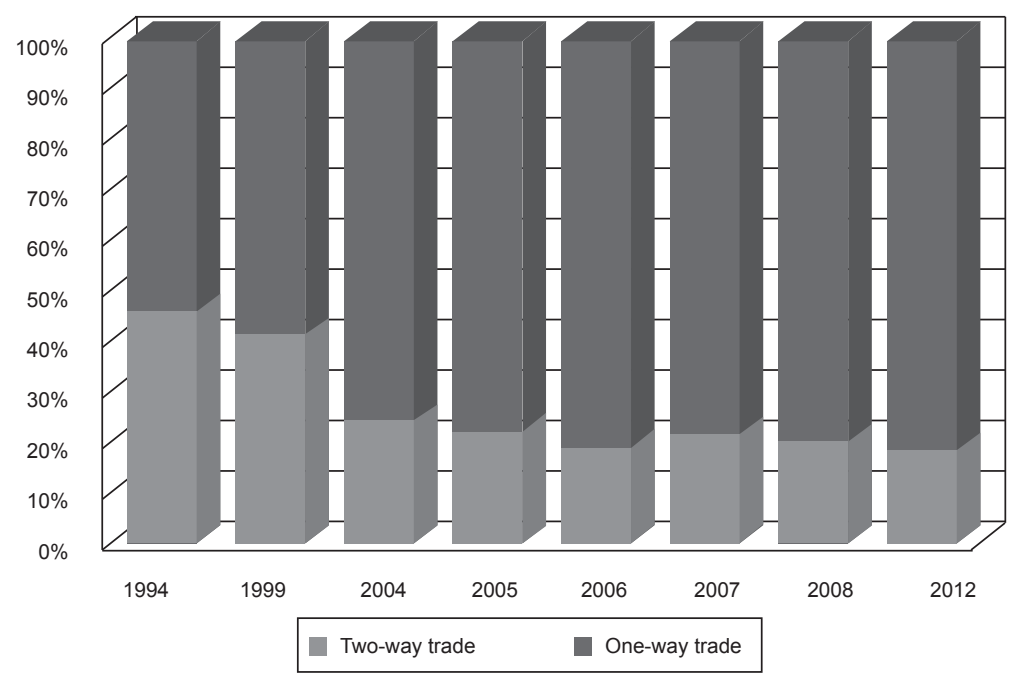

To ascertain which parts and components products experienced large amounts of two-way trade, the estimates of the degree of IIT (as measured by the G-L index) and the level of IIT for the top 10 parts and components products over the period 1994-2012 are identified in table 5. It is observed that most of these products are identical to those in table 3 , suggesting that the products that constitute the top 10 exported products in the parts and components manufactured goods category have also been the elements in two-way trade due to IIT. In 2012, the top three products that involved a high volume of IIT were SITC 78439, 79295 and 71392 (auto parts, parts of data processing machines and parts of power generating machinery), two of which were also ranked the same in 1994. The value of IIT in SITC 78429 increased from $\$ 1.059$ billion in 2004 to $\$ 4.746$ billion by 2012 . A similar increase was also noted for SITC 71392. Overall, it is observed that the amount of IIT for parts of machinery and automobile and other vehicle parts increased over the past decade, suggesting an increasing level of two-way trade in these products, possibly involving production fragmentation. 


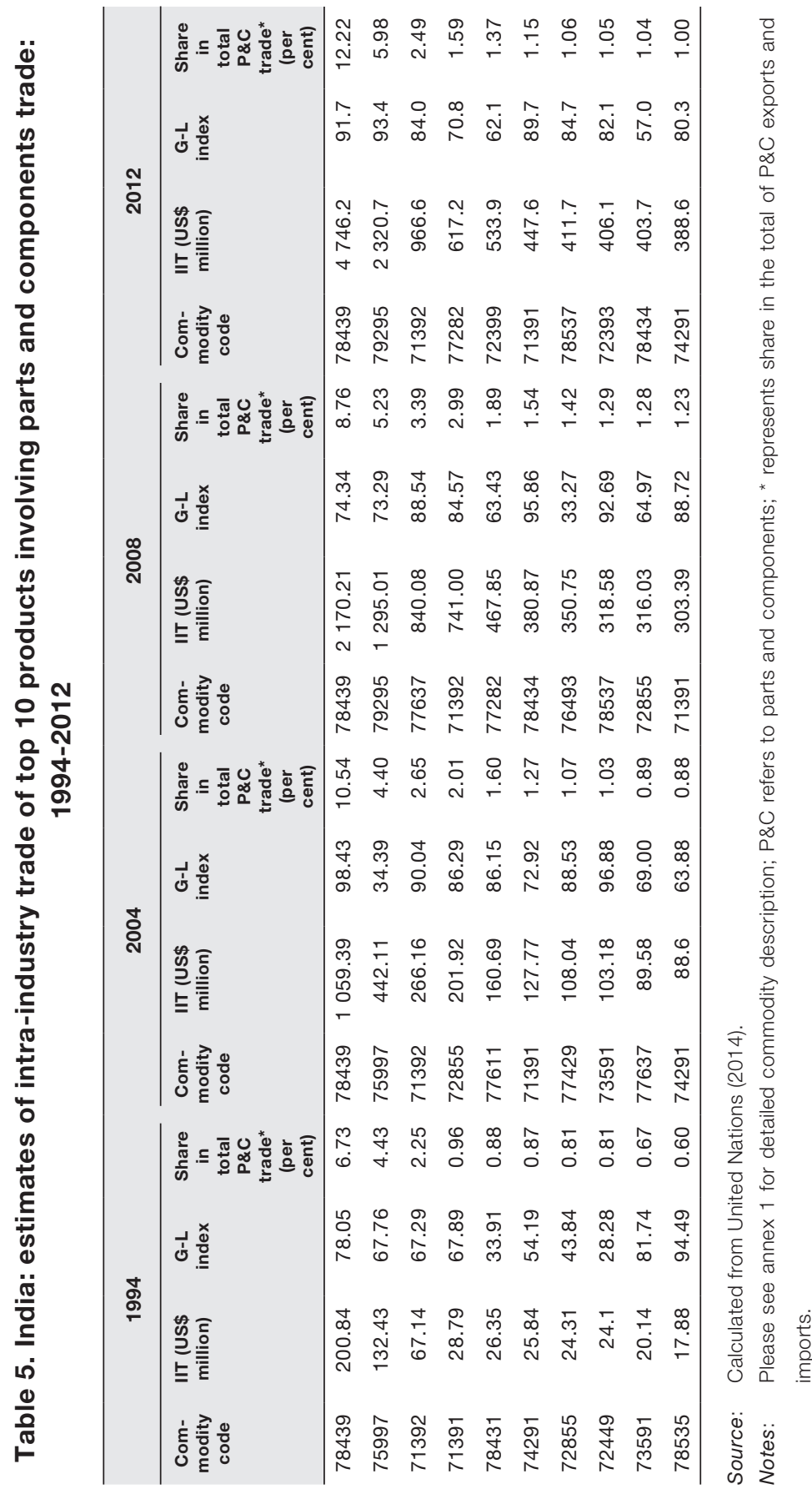


It is, however, important to further ascertain whether IIT was driving total trade in those parts and components products over the three time periods, and the extent to which its involvement changed over the years, which can be estimated through the MIIT index.

The MIIT estimates for the top 10 parts and components products involving the highest levels of IIT in 2008 and 2012 are presented in table 6. It is observed that while MIIT estimates were more of the intra-industry variety for seven of those products in 2012 compared to 1994, as well as in 2008, compared to 1994. Over the period 2008-2012, only three products (SITC 71392, 72393 and 78434) involved MIIT of the complete inter-industry variety, with seven products involving marginal trade of the intra-industry type. This is in line with the observation of Veeramani (2002, 2009) that with trade liberalization, IIT of India has expanded in the manufacturing sector.

Furthermore, it is also observed that the product SITC 78439, which involved automobile parts, constituted the highest share of the export of parts and components (21.4 per cent). This product experienced one of the highest levels of IIT over the period 1994-2012, and also showed a continuous increase in marginal IIT over the same period.

The above analysis does not suggest whether the observed marginal IIT in the seven parts and components product categories involve horizontal or vertical trade, and are of high or low quality. Figure 4 analyses this through the estimates of the ratio of unit values of exports to imports, as explained in equation (5) for the seven parts and components products whose MIIT estimates are not of the intra-industry variety. It is observed that all these products involved VIIT, suggesting evidence of production fragmentation in them. With the exception of SITC 79295 (aircraft and helicopter parts), none of the other parts and components products involved highquality VIIT in 2012. This indicated that with regard to the aircraft and helicopter parts industry, India is exporting higher quality parts and components than it is importing, and thus, moving up the quality ladder of its global value chain.

The products with the second highest in the quality spectrum are SITC 78439 (auto parts), followed by SITC 71391 (parts of spark-ignition internal combustion piston engines). For both of these products, albeit of low-quality VIIT, the unit value ratios of exports to imports improved. This suggests an overall quality improvement in these two products (SITC 78439 and SITC 71391) over the period, exporting lower quality parts and component goods, while importing higher quality ones for its domestic market. Notably, the share of total parts and components exports for SITC 71391 declined from 4.4 per cent to 1.7 per cent over the period 1994-2012, while that of SITC 79295 and SITC 78439 nearly doubled from 16.6 per cent to 32.0 per cent. 
Table 6. India: estimates of marginal intra-industry trade in the top 10 products involving parts and components trade in 2008 and 2012

\begin{tabular}{cccc}
\hline $\begin{array}{c}\text { Commodity } \\
\text { code }\end{array}$ & $\begin{array}{c}\mathbf{2 0 0 8} \\
\text { (over 1994) }\end{array}$ & $\begin{array}{c}\mathbf{2 0 0 8} \\
\text { (over 1999) }\end{array}$ & $\begin{array}{c}\mathbf{2 0 0 8} \\
\text { (over 2004) }\end{array}$ \\
\hline 78439 & 74.0 & 75.3 & 48.2 \\
79295 & 48.4 & 70.4 & 40.4 \\
77637 & 87.3 & 88.9 & 91.3 \\
71392 & 78.4 & 88.6 & 98.6 \\
77282 & 64.9 & 66.2 & 77.0 \\
78434 & 95.5 & 94.6 & 0.0 \\
76493 & 34.4 & 36.3 & 28.8 \\
78537 & 71.2 & 40.4 & 55.3 \\
72855 & 67.7 & 63.6 & 42.2 \\
71391 & 82.6 & 99.5 & 65.2 \\
\hline
\end{tabular}

\begin{tabular}{cccc}
\hline $\begin{array}{c}\text { Commodity } \\
\text { code }\end{array}$ & $\begin{array}{c}\mathbf{2 0 1 2} \\
\text { (over 1994) }\end{array}$ & $\begin{array}{c}\mathbf{2 0 1 2} \\
\text { (over 2004) }\end{array}$ & $\begin{array}{c}\mathbf{2 0 1 2} \\
\text { (over 2008) }\end{array}$ \\
\hline 78439 & 90.1 & 89.8 & 47.7 \\
79295 & 79.4 & 76.0 & 57.0 \\
71392 & 85.6 & 75.3 & 0.0 \\
77282 & 72.2 & 83.5 & 89.1 \\
72399 & 65.3 & 70.5 & 95.1 \\
71391 & 85.8 & 77.8 & 92.0 \\
78537 & 55.6 & 43.9 & 30.1 \\
72393 & 87.2 & 99.9 & 0.0 \\
78434 & 56.9 & 57.0 & 0.0 \\
74291 & 83.1 & 85.6 & 94.8 \\
\hline
\end{tabular}

Source: Calculated from United Nations (2014).

Note: Please see annex 1 for detailed commodity description. 


\section{Figure 4. Estimates of vertical intra-industry trade in selected parts and components exports over 1994-2012}

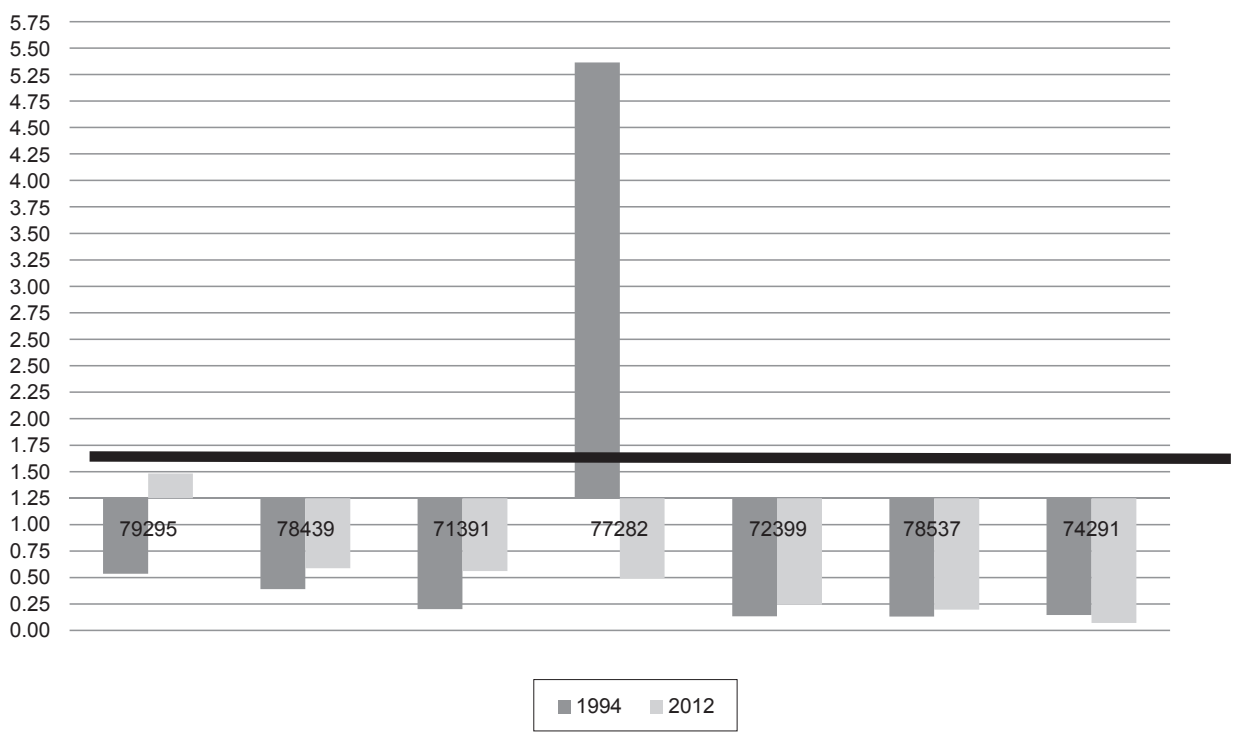

Source: $\quad$ Author's calculations based on United Nations (2014).

Note: $\quad$ An estimate of vertical intra-industry trade less than 0.75 suggests lower quality VIIT (LVIIT), while that greater than 1.25 suggests higher quality VIIT (HVIIT).

The above results suggest that production fragmentation is emerging in the trade of manufactured goods, which is concentrated in SITC 7 (machinery and transport equipment) and more specifically in aircraft and auto parts and component products, based on evidence seen over the period 1994-2012. Furthermore, while India is a net exporter of aircraft parts and auto parts (tables 3 and 4), the former involves production fragmentation at the higher end of the value chain and quality spectrum than the latter, as argued in the theoretical and empirical literature.

The next step in analysing the trends in production fragmentation in auto parts and components is to decompose auto parts and components specifically into oneway, two-way, horizontal and vertical IIT in order to estimate the extent to which this sector is experiencing production fragmentation over the four time points: 1994, 2004, 2008 and 2012, and to determine the leading product categories extending upon the Amighini (2012) framework. The auto parts and components consist of 30 products, 21 of which are classified in SITC 5-digit categories belonging to SITC 7 and 8 whose intra-industry trends were estimated earlier. The remaining nine 
product categories involve parts of tyres and tubes, all of which are confirmed to have experienced two-way trade. ${ }^{21}$

Table 7 summarizes the trends in trade values and trade patterns in the automobile parts and components industry over the sample period. It is observed that while trade volumes have expanded significantly, the trade balance has turned into a deficit, indicating that India had been a net importer in this industry over the past two decades. One-way trade in auto parts and components declined by almost a half over the period 1994-2004, with the share of two-way IIT about 85.4 per cent, which was unchanged in 2012 when compared with 2004.

Decomposing two-way trade, it is further observed that VIIT dominated IIT in this industry, with its share increasing to 84.2 per cent in 2012 compared to 71.6 per cent in 1994. This VIIT was predominantly in the low-quality range, constituting nearly 78.4 per cent of total two-way trade in automobile parts and components, covering 27 out of 30 products. ${ }^{22}$ The single largest product category in this industry is SITC 78439. This product, which also experienced VIIT of a low quality and increased IIT at the margin over the period 1994-2012, constituted 44.7 per cent of the total trade in auto parts and components in 2012.

The above, therefore, corroborates the findings of recent studies of Amighini (2012), Athukorala (2013) and Tewari, Veeramani and Singh (2015) that automobile parts and components appear to be the only industry experiencing international production fragmentation due to an increase in vertical IIT, albeit of a low quality. This study also confirms that the production fragmentation is largely restricted to one product category, namely SITC 78439 (other parts and accessories of tractors, and motor vehicles for the transport of goods, persons and special-purpose motor vehicles). ${ }^{23}$

\footnotetext{
21 See Amighini (2012) for the product list on the auto parts and components industry.

22 The detailed product level analysis for all 30 individual auto parts and component products are available from the authors on request. These include SITC 62559 (tyres, pneumatic, new and other) which comprised the second highest share of total auto parts trade in 2012 . There was no change for this product in the VIIT quality ladder over the period 1994-2012.

23 This category concords to 8 HS2007 6-digit products (870870, 870880, 870891, 870892, 870893, $870894,870895$ and 870899$)$ that includes auto parts, such as clutches, radiators, exhaust pipes, steering wheels.
} 
Table 7. India: analysis of intra-industry trade in auto parts and components in trade, 1994-2012

\begin{tabular}{lrrrr}
\hline & \multicolumn{1}{c}{$\mathbf{1 9 9 4}$} & \multicolumn{1}{c}{$\mathbf{2 0 0 4}$} & \multicolumn{1}{c}{$\mathbf{2 0 0 8}$} & \multicolumn{1}{c}{$\mathbf{2 0 1 2}$} \\
\hline Exports (US\$ million) & 317.7 & 944.5 & 2577.6 & 5440.0 \\
Imports (US\$ million) & 269.6 & 904.4 & 3578.1 & 6138.5 \\
Total value of trade (US\$ million) & 587.3 & 1848.9 & 6155.7 & 11578.5 \\
Trade balance (US\$ million) & 48.1 & 40.1 & -1000.5 & -698.5 \\
Trade pattern (\% of auto parts & & & & \\
and components sector) & & & & \\
One-way & 27.1 & 14.6 & 13.2 & 14.6 \\
IIT & 72.9 & 85.4 & 86.7 & 85.4 \\
Horizontal IIT & 1.3 & 10.00 & 3.2 & 1.2 \\
Vertical IIT & 71.6 & 75.4 & 83.5 & 84.2 \\
Vertical IIT (HQ) & 2.22 & 5.9 & 3.0 & 5.8 \\
Vertical IIT (LQ) & 69.38 & 69.5 & 80.5 & 78.4 \\
Share of single largest product & 43.8 & 54.5 & 47.4 & 44.7 \\
(78439) & & & & \\
\hline
\end{tabular}

Source: Calculated from United Nations (2014).

Notes: $\quad$ See Amighini (2012, p. 340, appendix A, table A1) for detailed commodity description of products included in auto parts and components industry.

Anecdotal evidence supports this trend at the firm level. ${ }^{24}$ The experience of the TVS group's Sundaram Fasteners Ltd. as the preferred supplier of radiator caps for United States-based General Motors, and that of Toyota Kirloskar auto parts (a joint venture between Toyota of Japan and a local manufacturer in India) in exporting gearboxes from India to assembly plants in Argentina, South Africa and Thailand, confirms this trend at the firm level. While one example involves an arms-length transaction and the other involves FDI, it clearly shows the emergence of production fragmentation in the auto parts industry in recent years. However, India continues to export lower quality auto parts and import higher quality ones for its domestic market, which is exactly the reverse of that of its major competitors in this industry in East Asia and Europe.

There is also increasing evidence to suggest that the aircraft parts and components industry (SITC 79295) is also playing an important role in the emergence of India in global production fragmentation in the trade of manufactured goods. According to Workman (2015), India was the 11th largest exporter of aircraft parts in

24 See Tewari, Veeramani and Singh (2015); Nag (2011); Athukorala (2013). 
2014, with a share of 2.4 per cent of world exports of aircraft parts, compared with a share of 1.2 per cent in 2012. India along with Singapore was the only non-OECD Asian developing country to be among the world's largest aircraft parts exporters. Tatas, UTC Aerospace Systems (UTAS), Hindustan Aeronautics Limited (HAL), Dynamatic, Aequs, and Moog are firms in India that export aircraft parts, to leading aerospace manufacturers, such as Boeing, Airbus, Lockheed Martin and Sikorsky. ${ }^{25}$

Mukherjee (2015) and Singh (2015) note that this sector has contributed to the success of the recently announced "Make in India" initiative by the Indian Prime Minister in 2014. Exports of aircraft parts and components from India grew by 58 per cent growth observed in aircraft parts and components exports from India, mainly involving small and medium enterprises, during the period April-November 2014 compared with the same period in 2013. This export market was expected to be at least $\$ 4$ billion over the period April-November 2014, compared with $\$ 8.13$ million in 2012.

More recently, liberalized policies in January 2015, such as the Federal Aviation Administration (FAA) direct approval of two aircraft parts developed in India for use by manufacturers in the United States, provides further opportunities for Indian firms to remain globally competitive in this industry, specifically with regard to higher-quality VIIT products. These products, certified as part of the country's Bilateral Aviation Safety Agreement with the United States, includes a four-person life raft developed by the Indian arm of UTC Aerospace Systems and nickel-cadmium batteries developed by Hyderabad-based HBL Power Systems, which will no longer be subject to multiple checks across borders when shipped and certified to be used directly by United States aircraft manufacturers.

\section{POLICY IMPLICATIONS AND CONCLUDING REMARKS}

The study at the product level confirms that the aircraft parts and automobile parts and components industry became an emerging area of production fragmentation in the trade of manufactured goods in India over the period 1994-2012. Aircraft parts (SITC 79295) is the only parts and components product to experience this at the higher end of the global value chain; the auto parts and components industry is found to experience this primarily at the lower end of the value chain. Unlike East Asia, there is no direct empirical evidence to support that FDI has played a role in such production fragmentation in India. This is mainly due to the unavailability of statistics on intra-firm trade that establishes the link between fragmentation and the role of

25 Aircraft parts exported by India includes floor beams for Boeing, doors for Airbus A320 doors as well as flap track beams and helicopter cabins for other aircraft manufacturers (Mukherjee, 2015). 
multinationals. The above identified products are, however, likely to involve more of producer-driven fragmentation through activities of multinationals ${ }^{26}$ as argued in the theoretical literature.

The direct policy implication emerging for India is to harness the existing potential that exists in the auto parts industry and develop capabilities to climb the quality ladder in production fragmentation, which is currently experiencing low IIT. A key challenge for policymakers as they increasingly attempt to integrate with East Asia through RCEP and other regional trade and investment agreements, will be to urgently address the existing supply and demand side constraints on moving up the quality ladder in the global value chain of these network manufacturing trade products. The constraints are related to infrastructural bottlenecks that increase the cost of businesses as compared to other Asian economies, inflexibility in labour laws and the need to improve skill development and accumulation of human capital in the manufacturing sector. ${ }^{27}$

This study identifies sector-specific potential product categories wherein production fragmentation is emerging in the manufacturing trade. Future research in this area pertaining to sector-specific, firm level studies should, therefore, be explored in detail. Lessons learned from experiences of other East Asian countries in attracting export-oriented FDI to increase production fragmentation at the higher end of the value chain would also be useful for policymakers in the near future.

\footnotetext{
26 See section II and Gereffi (2001).
}

$27 \quad$ See Sen and Srivastava (2012); Athukorala (2013); Tewari, Veeramani and Singh (2015). 


\section{REFERENCES}

Abd-el-Rahman, K. (1991). Firms' competitive and national comparative advantages as joint determinants of trade composition. Weltwirtschaftliches Archiv, vol. 127, No. 1, pp. 83-97.

Aggarwal, A. (2001). Liberalisation, multinational enterprises and export performance: evidence from Indian manufacturing. Working Paper, No. 69. New Delhi, India: Indian Council for Research on International Economic Relations (ICRIER). Available from www.eldis.org/ vfile/upload/1/document/0708/DOC9489.pdf.

Amighini, A. (2012). China and India in the international fragmentation of automobile production. China Economic Review, vol. 23, No. 2, pp. 325-341.

Ando, M. (2006). Fragmentation and vertical intra-industry trade in East Asia. The North American Journal of Economics and Finance, vol. 17, No. 3, pp. 257-281.

Ando, M., and F. Kimura (2009). Fragmentation in East Asia: further evidence. ERIA Discussion Paper Series DP-2009-20 (October). Available from www.eria.org/ERIA-DP-2009-20.pdf.

Athukorala, P. (2005). Product fragmentation and trade patterns in East Asia. Asian Economic Papers, vol. 4, No. 3, pp. 1-27.

(2011). Production networks and trade patterns in East Asia: regionalization or globalization? Asian Economic Papers, vol. 10, No. 1, pp. 65-95.

(2013). How India fits into global production sharing: experience, prospects and policy options. Working Papers in Trade and Development, No. 2013/13 (August). Canberra: Australian National University

Athukorala, P., and N. Yamashita (2005). Production fragmentation and trade integration: East Asia in a global context. The North American Journal of Economics and Finance, vol. 17 , No. 3, pp. 233-256.

Brülhart, M. (1994). Marginal intra-industry trade: measurement and relevance for the pattern of industrial adjustment. Weltwirtschaftliches Archiv, vol. 130, No. 3. pp. 600-613.

Dixit, A.K., and J.E. Stiglitz (1977). Monopolistic competition and optimum product diversity. The American Economic Review, vol. 67, No. 3, pp. 297-308.

Durkin, Jr, J.T., and M. Krygier (2000). Differences in GDP per capita and the share of intraindustry trade: the role of vertically differentiated trade. Review of International Economics, vol. 8, No. 4, pp. $760-774$.

Felipe, J., U. Kumar, and A. Abdon (2013). Exports, capabilities, and industrial policy in India. Journal of Comparative Economics, vol. 41, No. 3, pp. 939-956.

Fontagne, L., and M. Freudenberg, (1997). Intra-Industry trade: methodological issues reconsidered. Working Papers, vol. 97, No. 1, Paris: CEPII.

Fujita, M. (2007). The development of regional integration in East Asia: from the viewpoint of spatial economics. Review of Urban \& Regional Development Studies, vol. 19, No. 1, pp. 2-20.

Fukao, K., H. Ishido, and K. Ito (2003). Vertical intra-industry trade and foreign direct investment in East Asia. Journal of the Japanese and International Economies, vol. 17, No. 4, pp. 468-506.

Gereffi, G. (2001). Shifting governance structures in global commodity chains, with special reference to the internet. American Behavioral Scientist, vol. 44, No. 10, pp. 1616-1637. 
Greenaway, D., R. Hine, and C. Milner (1995). Vertical and horizontal intra-industry trade: a cross industry analysis for the United Kingdom. The Economic Journal, vol. 105, No. 433, pp. 1505-1518.

Grossman, G.M., and E. Helpman, (2005). Outsourcing in a global economy. Review of Economic Studies, vol. 72, No. 1, pp. 135-159.

Grubel, Herbert G., and Peter J. Lloyd (1975). Intra-Industry Trade, the Theory and Measurement of International Trade in Differentiated Products. London: McMillan.

Helpman , E. (1984). A simple theory of international trade and multinational corporations. Journal of Political Economy, vol. 92, No. 3, pp. 451-471.

Helpman, E., and P.R. Krugman (1985). Market Structure and Foreign Trade: Increasing Returns, Imperfect Competition, and the International Economy. Wheatsheef Books, Harvester Press, MIT.

Hummels, D., J. Ishii, and K. Yi (2001). The nature and growth of vertical specialization in world trade. Journal of International Economics, vol. 54, No. 1, pp. 75-96.

Jiang, X., and W. Milberg (2012). Vertical specialization and industrial upgrading: a preliminary note. Capturing the Gains Working Paper, 10. Manchester, United Kingdom: University of Manchester.

Jones, R.W, and H. Kierzkowski (1990). The role of services in production and international trade: a theoretical framework. In The Political Economy of International Trade: Essays in Honor of Robert E. Baldwin, Ronald Jones and Anne Krueger, eds. Blackwells.

(2001). A framework for fragmentation. In Fragmentation: New Production Patterns in the World Economy, S.W. Arndt and H. Kierzkowski, eds. New York: Oxford University Press.

Kimura, F., and M. Ando (2005). Two-dimensional fragmentation in East Asia: conceptual framework and empirics. International Review of Economics and Finance, vol. 14, No. 3, pp. 317- 348.

Krugman, P. (1995). Growing world trade: causes and consequences. Brooking Papers on Economic Activity 25th Anniversary Issue, No. 1, pp. 327-377.

Kumar, N. (1990). Multinational Enterprises in India: Industrial Distribution, Characteristics and Performance. London and New York: Routledge.

(2003). Liberalization, foreign direct investment flows and economic development: the Indian experience in the 1990s. Research and Information System for Developing Countries (RIS) Discussion paper, 65. New Delhi.

Kumar, N., and N.S. Siddharthan, (1994). Technology, firm size and export behaviour in developing countries: the case of Indian enterprises. The Journal of Development Studies, vol. 31, No. 2, pp. 289-309.

Kuroiwa, I., and T.M. Heng, eds. (2008). Production Networks and Industrial Clusters: Integrating Economies in Southeast Asia. Singapore: Institute of Southeast Asian Studies.

Lüthje, T. (2001). Intraindustry trade in intermediate goods. International Advances in Economic Research, vol. 7, No. 4, pp. 393-408.

Mukherjee, S. (2015). Boost for make in India as FAA clears two plane parts. Indian Express, 12 January. 
Nag, B. (2011). Trade liberalization and international production networks: experience of the Indian automotive sector. In Fighting Irrelevance: The Role of Regional Trade Agreements in International Production Networks in Asia - A Study by the Asia-Pacific Research and Training Network on Trade, Mia Mikic and Mochamad Pasha, eds. Bangkok: ESCAP.

Ng, F., and A. Yeats (2001). Production sharing in East Asia: who does what for whom, and why? In Global Production and Trade in East Asia, L.K. Cheng and H. Kierzkowski, eds. Boston: Kluwer Academic Publishers.

(2003). Major trade trends in East Asia: what are their implications for regional cooperation and growth? Policy Research Working Paper, No. 3084, Washington D.C.: World Bank. Available from http://elibrary.worldbank.org/doi/pdf/10.1596/1813-9450-3084.

Pant, M. (1993). Export performance, transnational corporations and the manufacturing sector: a case study of India. Indian Economic Review, vol. 28, No.1, pp. 41-54.

(1995). Foreign Direct Investment in India: The Issues Involved. New Delhi: Lancer Books.

Pittiglio, R. (2014). An essay on intra-industry trade in intermediate goods. Modern Economy, vol. 5, pp. 468-488. Available from http://dx.doi.org/10.4236/me.2014.55045.

Rajan, R., and R. Sen (2002). A decade of trade reforms in India: how it compares with East Asia. World Economics, vol. 3, No. 4, pp. 1-14.

Rajan, R.S. (1996). Measures of intra-industry trade reconsidered with reference to Singapore's bilateral trade with Japan and the United States. Weltwirtschaftliches Archiv, vol. 132, No. 2, pp. 378-389.

(2003). Production sharing in East Asia: implications for India. Economic and Political Weekly, vol. 38, No. 36 (September), pp. 3770-3772.

Sen, Rahul, and Sadhana Srivastava (2012). Asia's international production networks: will India be the next assembly centre? ARTNeT Working Paper Series, No. 118 (August). Bangkok: ESCAP. Available from www.artnetontrade.org.

Singh, A. (2015). Aircraft, spacecraft parts exports grow 58\%. Deccan Herald, 21 January.

Srivastava, S., and R. Sen (2011). Is production fragmentation emerging in India's manufacturing trade? ASCl Journal of Management, vol. 40, No. 2, pp. 73-100.

Tewari, M., C. Veeramani, and M. Singh (2015). The potential for involving India in regional production networks: analyzing vertically specialized trade patterns between India and ASEAN. ICRIER Working Paper, No. 292. Available from http://icrier.org/pdf/Working_Paper_292.pdf.

Turkcan, K., and A. Ates (2010). Structure and determinants of intra-industry trade in the US autoindustry. Journal of International and Global Economic Studies, vol. 2, No. 2, pp. 15-46.

United Nations (2014). The United Nations Commodily Trade Statistics Database (UN Contrade). New York. Available from comtrade.un.org/. Accessed 5 February 2014.

Veeramani, C. (2002). Intra-industry trade of India: trends and country-specific factors. Weltwirtschaftliches Archiv, vol. 138, No. 3, pp. 509-533.

(2009). Trade barriers, multinational involvement and intra-industry trade: panel data evidence from India. Applied Economics, vol. 41, No. 20, pp. 2541-2553.

Workman, D. (2015). Aircraft parts exports by country, November. Available from www. worldstopexports.com/aircraft-parts-exports-country/3340. 
World Bank (2012). World Development Indicators 2012. Washington D.C.

World Trade Organization (2013). International Trade Statistics. Geneva.

Yi, Kei-Mu (2003). Can vertical specialization explain the growth of world trade. Journal of Political Economy, vol. 111, No. 1, pp. 52-102. 


\title{
Annex 1
}

\section{Detailed commodity description of selected products in trade of parts and components in India ${ }^{a}$}

\author{
Commodity \\ code \\ Description \\ 71323 Compression-ignition engines (diesel or semi-diesel engines)
}

$71391 \quad$ Parts, n.e.s., suitable for use solely or principally with spark-ignition internal combustion piston engines

71392 Parts, n.e.s., suitable for use solely or principally with compression-ignition internal combustion piston engines

71499 Parts for gas turbines, n.e.s.

72393 Parts for boring or sinking machinery

72399 Parts, n.e.s., of civil engineering etc. machinery, including mining and public works machinery parts (Heading 723) and cranes etc. (Heading 744.3)

72449 Parts and accessories of textile machinery designed for use in the preparation and production of textile fibers and yarns

72855 Parts, n.e.s., of machinery for public works etc., preparing animal or fixed vegetable fats and oils, and specialized for particular industries, n.e.s.

73591 Parts, n.e.s., and accessories suitable solely or principally for use with metalworking machine tools working by removing metal or other material

$74291 \quad$ Parts of pumps for liquids

74494 Parts of lifting, handling, loading or unloading machinery, n.e.s.

75997 Parts of automatic data processing machines and units thereof, magnetic or optical readers, and machines for transcribing and processing data, n.e.s.

$76491 \quad$ Parts of electrical apparatus for line telephony or line telegraphy (including apparatus for carrier-current line systems)

76493 Parts of television receivers, radiobroadcast receivers, transmission apparatus for radio telephony, telegraphy, broadcasting or television etc.

77249 Electrical apparatus for switching or protecting electrical circuits, or making connections to or in electrical circuits, n.e.s., exceeding 1,000 volts

77282 Parts of electrical apparatus for switching or protecting electrical circuits for making connections to or in electrical circuits, n.e.s.

77611 Television picture tubes, colour

77637 Photosensitive semiconductor devices; light emitting diodes

$77643 \quad$ Non-digital monolithic integrated units

77812 Electric accumulators (storage batteries)

77885 Parts of electric sound or visual signaling apparatus, n.e.s. (including parts of indicator panels, burglar and fire alarms) 


\section{Annex 1 (continued)}

\begin{tabular}{|c|c|}
\hline $\begin{array}{l}\text { Commodity } \\
\text { code }\end{array}$ & Description \\
\hline 77886 & $\begin{array}{l}\text { Carbon electrodes, carbon brushes, lamp carbons, battery carbons and other } \\
\text { carbon articles, with or without metal, of a kind used for electrical purposes }\end{array}$ \\
\hline 78431 & $\begin{array}{l}\text { Bumpers and parts thereof, for tractors, motor cars and other motor vehicles, } \\
\text { etc. }\end{array}$ \\
\hline 78434 & Gear boxes \\
\hline 78439 & $\begin{array}{l}\text { Parts and accessories n.e.s. for tractors, motor cars and other motor vehicles, } \\
\text { trucks, public-transport vehicles and road motor vehicles, n.e.s. }\end{array}$ \\
\hline 78537 & $\begin{array}{l}\text { Parts and accessories for bicycles and other cycles (except motorcycles and } \\
\text { mopeds), n.e.s. }\end{array}$ \\
\hline 79295 & Parts of airplanes or helicopters, n.e.s. \\
\hline 79297 & Other parts of the goods of group 792 \\
\hline 89410 & Baby carriages, and parts thereof, n.e.s. \\
\hline
\end{tabular}

Source: United Nations (2014).

Note: $\quad$ a Represents only those parts and components commodities that constituted the top 10 items of exports from India (see table 3); imports (see table 4), intra-industry trade (see table 5) and intra-industry trade (including vertical intra-industry trade - see figure 4) during the chosen period of the study; for a complete description of all parts and components traded goods, see Athukorala (2005); n.e.s. refers to not elsewhere specified. 